\title{
A Framework for Improving Customer Loyalty at Retailers in Jeddah City: A Case Study
}

\author{
Hemaid Alsulami \\ Industrial Engineering Department, Faculty of Engineering, King Abdulaziz University, Jeddah, KSA \\ Email: healsulami@kau.edu.sa
}

How to cite this paper: Alsulami, $\mathrm{H}$. (2021). A Framework for Improving Customer Loyalty at Retailers in Jeddah City: A Case Study. American Journal of Industrial and Business Management, 11, 973-983. https://doi.org/10.4236/ajibm.2021.119059

Received: August 8, 2021

Accepted: September 15, 2021

Published: September 18, 2021

Copyright $\odot 2021$ by author(s) and Scientific Research Publishing Inc. This work is licensed under the Creative Commons Attribution International License (CC BY 4.0).

http://creativecommons.org/licenses/by/4.0/

\begin{abstract}
Customers are an integral part of any business; therefore, organizations have to build their customer loyalty in order to achieve long-term profitability. Supermarkets, in their efforts to achieve customer satisfaction, try to be more creative and engaged with their customers in order to get their loyalty. This study aims to explore the relationship between customer satisfaction and customer loyalty in supermarket retailers in Jeddah city, Saudi Arabia. In addition, factors affecting customer loyalty and customer loyalty programs are analyzed by conducting an empirical study. The results show the factors that encourage customer loyalty to a specific supermarket are the location of the supermarket, price, variety of products, promotion activities and membership, respectively.
\end{abstract}

\section{Keywords}

Customer Loyalty, Customer Management, Customer Satisfaction

\section{Introduction}

Customers are an integral part of any business; the main purpose for all businesses is to satisfy customer needs and generate profit for itself. Because customers are an essential source of revenue, it is important to define how customers prioritize product or service costs, delivery time, variety and quality in order to satisfy their expectations through its product or service. When organizations build customer loyalty, they can achieve long-term profitability. Loyalty is not just about continuing to buy from the organization. Customers might repeat purchasing for many reasons rather than being loyal, for example, if the organization provides the lowest cost in the market, if there is a contractual arrangement with the organization, if it takes too much effort or money to change suppliers or if shopping there has become a habit. Loyalty also involves a customer 
believing that the products or service offers of the organization are the best option. Organizations must put effort into highly satisfying their customers to enhance customer loyalty, thereby enabling them to increase the sales of newly launched products and protect them from their competitors (Gobiraj \& Nimalathasan, 2011). Studies have also shown that keeping existing customers is more profitable than acquiring new customers, since the cost of retaining old customers is less than generating new customer demand (2011).

Most organizations seek to gain a competitive advantage by exceeding customer expectations, not just satisfying them (Kotler, 2003). Nowadays, customers have access to a variety of data on many organization sectors, so they are willing to monitor the trade of many competitors and stick with organizations that provide competitive customer experience. Hence, it is more difficult to build customer loyalty.

Supermarkets are one of the most important retailers for customers where they can buy their needs for life. Recently loyalty has become a major focus for supermarkets as a way to measure their success, increase their productivity and raise profits. Loyalty can be defined as "A customer continuing to believe that your organization's product/service offer is their best option. It best fulfills their value proposition whatever that may be. They take that offer whenever faced with that purchasing decision" (Ranade, 2012). According to the previous definition, customer loyalty is more than just a customer returning to the same store for their needs each time. It is a relationship where the more you receive. Therefore, loyalty is a relationship, the more you provide the more you receive, which means that supermarkets have to provide promotions, discounts or offers to customers in order to enhance the relationship and to create loyalty.

Supermarkets nowadays seek to gain customers' loyalty through different ways to make customers feel precious. So loyalty can achieve through offers, discounts and quality servicers/products. Therefore, customers will be loyal when the supermarkets understand and study well the customers' desired needs. The main idea is to know how loyalty affects the customer's behavior and their action to determine the best way that let supermarkets increase loyalty.

This paper analyzes the relationship between customer satisfaction and customer loyalty in Jeddah supermarkets. It seeks to identify the main factors that affect customer loyalty among supermarket retailers. This will help to establish loyalty programs that would increase the probability of customers giving supermarkets repeat business. Supermarkets in Jeddah city are not providing much attention to customer loyalty. They might have little awareness of the factors that enhance customer loyalty or about applicable loyalty programs. This study aims to enhance and improve the awareness of Jeddah supermarkets' customer loyalty through conducting an empirical study to assess the main factors affecting loyalty. It examines how customer satisfaction correlates with their loyalty to the supermarket. Furthermore, the study analyzes different kinds of loyalty programs in order to determine the most effective program for customers. 


\section{Literature Review}

Customer loyalty is to be committed to re-buying a preferred product or service in the future. Companies consider customer loyalty to be a key factor for their success. In the 1980's companies spent millions on developing customer relationship management programs in order to build customer loyalty. Nowadays, customer loyalty is even more important due to an increase in competition and the fact that customer loyalty doesn't only apply to purchasing a product or service; customers can recommend the product or service to a friend or associates (Khan, 2013).

Customer loyalty nowadays has become an important factor that can increase a business' competitiveness and affect marketing. Customer loyalty is considered an intangible asset in business. Research has shown that brand loyalty is linked to business performance (Reichheld, 2003). To define the loyalty is the reflecting of how likely the customers will be able to switch to different brand market especially when other market is providing a different price, product, services and communication. So loyalty affecting the customer's feedback and their action to determined which brand or market to go to. Finding an accurate measure of customer loyalty is essential important due to its link with profitability (Reichheld, 2003; Salegna \& Goodwin, 2005). Most studies categorize customer loyalty to one of two types: either attitudinal or behavioral (Moisescu, 2014).

The success of any organization depends on customer satisfaction with the organization. When a customer is satisfied he will most likely be loyal to this organization. A study was conducted on five supermarkets in the city of London which were selected as cluster sampling (Gandhi, Gobiraj, \& Nimalathasan, 2010). Ten customers from each supermarket answered a questionnaire that used a seven-point Likert scale to measure satisfaction. This study found that $77.89 \%$ of the total variance was accounted by nine factors out of 27 . These factors are: sales promotion, provision of information, management, recommendation of the product or service, new brand, the value of brand, innovative, benchmarking and environmentally friendly organization. The study advises the following to help improve customer loyalty: 1) Customer care should be improved to make the customer satisfied with the service and therefore loyal; 2) Employee training is important as good staff with proper training should help keep customers satisfied; 3) Providing a wide variety of products that covers the needs of different ethnic groups; 4) Having good infrastructure, including comfortable facilities, good location, adequate parking spaces, fair prices, and a friendly atmosphere. All of these factors help to ensure that the customer is happy and satisfied (Gandhi, Gobiraj, \& Nimalathasan, 2010).

The supply chain macro is divided into three categories: Customer Relationship Management (CRM), internal supply chain management (ISCM) and supply Relationship Management SCM. This study focuses on CRM and its relationship with the customer loyalty. CRM describes the relationship between the organization and its customers and focuses on the interface. The aim of developing CRM is to increase the profits of the organization and customer satisfac- 
tion. Since customer satisfaction and customer loyalty is one of the highest priorities of any organization to get success. When customer satisfaction reaches a certain level, the customer takes on the role of free advertiser for that organization (Gandhi, Gobiraj, \& Nimalathasan, 2010). Previous research has shown that the cost of maintaining existing customers is less than the cost of finding new ones. Therefore, increasing customer loyalty should be a part of any CRM strategy. Of course, each organization has its own CRM strategy. Different factors that make the customer satisfied and be loyal are behavior of employee, quality of customer services, relationship development and interaction management (Long \& Khalafinezhad, 2012).

During the present economic crisis, customers have started to spend less and save more. To compete in this crisis, companies are using several mechanisms to increase their number of shoppers such as promotions, providing goods at lower prices and offering more rewards to loyal customers. To generate more profits, loyal customers can help to increase purchases, reduce operating cost and to increase profit margin. Companies have discovered that they can survive in this competition when they establish a deeper relationship with their customers. Many companies have developed a customer relationship management (CRM) system that would help to capture and analyze customer information. This information allows them to divide their customers into categories depending on demographics, preference, etc., which helps them to customize services or products or to customize rewards to suit customers. Recently research and survey studies indicate that over 55 percent of CRM failed for several reasons: lack of support of top management, lack of customer trust, etc. T\&T, an Australian supermarket, conducted a study to examine the pros and cons of different types of loyalty programs (Ho, 2009). They analyzed different loyalty programs adapted by competitors to enable them to examine the feasibility of developing loyalty programs. After this study they introduced four VIP loyalty programs. The study proposed different features of rewards for four different types of customers (Ho, 2009).

Several studies defined that there is a significant impact of customer brand identification on customer brand loyalty, whether it is direct or indirect. An empirical study by Nikhashemia, Paimb, Osmanc, and Sidind (2015) of the customers of Malaysian hypermarket customers found three factors that have a significant effect on brand loyalty: customer brand identification, brand trust and word-of-mouth communication. They determined that word-of-mouth communication had a greater positive effect than the brand trust factor. Also, they found that customer brand identification has an indirect effect on customer loyalty, not a direct effect as some studies conclude, since it has a key role in building customer loyalty via brand trust and word-of-mouth communication. In addition, Terblanche (2011) found that word-of-mouth communication is affected by many factors. It is affected directly by store image dimensions of utilitarian value, staff competence and store image congruence. The utilitarian value refers to the customer satisfaction about the end result of a consumption activity. On the other hand, staff competence concentrates on staff attitudes, beha- 
viors, experience and their ability to inspire and help the customer. The last factor, image congruence, relates to the relationship between store image and customer self-image. Nevertheless, the study also found that other factors that affect word-of-mouth communication indirectly such as merchandise quality and variety and accessibility of location via cumulative satisfaction and loyalty (Terblanche, 2011).

In Summary, the literature review shows that there is a need to analyze the relationship between customer satisfaction and customer loyalty in different cities based on the customers' behavior. Nevertheless, it is important to identify the main factors that affect customer loyalty among supermarket retailers. Supermarkets in Jeddah city are not paying much attention to customer loyalty. Therefore, there is a need to study Jeddah supermarkets customer's loyalty through conducting an empirical study to assess the main factors affecting loyalty and examine how customer's satisfaction correlates with their loyalty to the supermarket.

\section{Methodology}

This study aims to explore the relationship between customer satisfaction and customer loyalty in supermarket retailers in Jeddah city. In addition, the factors affecting customer loyalty and customer loyalty programs will be analyzed. All these analyses are in order to identify the most suitable programs that would enhance loyalty. After reviewing the relevant literature, a questionnaire was developed, surveying consumers among various supermarkets in Jeddah city.

To achieve the research objective, a survey questionnaire was applied to investigate the satisfaction and behaviors of customers towards various supermarkets in Jeddah. The questionnaire was distributed to a handiness sample of 2000 Jeddah supermarket customers in five major strata: Danube's consumers, Panda's consumers, Manuel's consumers, The Farm's consumers and Al-Rayah's consumers.

The questionnaire analyzes customer loyalty in the five leading retail supermarkets in Jeddah. The survey questions were validated based on experts' advice and information from relevant literature.

\section{Data Analysis}

The number of family members was an important factor to consider when examining customer loyalty, because bigger families always tend to go to the best supermarket that give good services and prices that suit their budget. In looking at number of family members, the largest group, $72.8 \%$, had more than four members in the family. However, to know what the favorite supermarket for the targeted segment is, most of the responses were equal, 37\% for Panda and 37\% for Al-Danube. To study the main reasons why customers like to visit a specific supermarket, the options that were given included price, verity of product, promotion activity, membership and location of the supermarket.

The findings are summarized and presented in Table 1 below. 
Table 1. Extent to which selected factors affect customer loyalty.

\begin{tabular}{|c|c|c|c|c|c|c|c|}
\hline \multirow{2}{*}{$\begin{array}{l}\text { Extent to which selected } \\
\text { factors affect customer } \\
\text { loyalty }\end{array}$} & \multicolumn{5}{|c|}{ Response (\%) } & \multirow{2}{*}{ Mean } & \multirow{2}{*}{ Ranking } \\
\hline & Panda & Al-Danube & Al-Raya & Manuel & Farm & & \\
\hline Price & 91 & 52 & 29 & 17 & 15 & 40.8 & 2 \\
\hline variety of products & 91 & 54 & 16 & 18 & 25 & 40.8 & 2 \\
\hline Promotion activities & 81 & 58 & 23 & 23 & 18 & 40.6 & 3 \\
\hline Membership & 74 & 61 & 27 & 17 & 25 & 40.4 & 4 \\
\hline $\begin{array}{l}\text { The location of the } \\
\text { supermarket }\end{array}$ & 82 & 57 & 27 & 27 & 16 & 41.8 & 1 \\
\hline \multicolumn{8}{|c|}{$\mathrm{N}=2000$} \\
\hline
\end{tabular}

The reason for customers to be not interested in customer loyalty programs was because $71.5 \%$ of customers didn't know about loyalty programs. When customers were asked what they thought the best way to increase the awareness of loyalty programs was, $50 \%$ of the responses suggested using SMS messages, $20 \%$ brochures, $18.5 \%$ internet advertising and $11.5 \%$ posters (Table 2 ).

The favorite type of loyalty program for customers, with $49.5 \%$ choosing it, was one that gave discounts. Loyalty programs were shown to affect purchase activities and 53\% of customers are willing to spend more money on buying goods from these supermarkets that over such programs (Table 3 ).

In addition, most of the participants, around 85\%, strongly agreed that having a loyalty card would make them want to shop at that supermarket more frequently.

\section{Results and Discussion}

This paper concentrates on the factors that affect supermarket customers' loyalty. Therefore, beside the field survey that was distributed and analyzed. The secondary data was information from supermarket websites and previous studies related to the research topic and findings. The analyses of the two types of data were linked in order to enhance the findings of the study and reduce the prejudice and bias for the readers.

The study found that Danube and Panda are the two supermarkets in Jeddah that have the most developed loyalty rewards programs. Actually, they have a strong CRM, since they support their supermarket with high customer services quality and continuous improvement of customer relationship. Nevertheless, the results of the survey found that customer satisfaction encourages customers to repeat their visit and be more loyal to the supermarket. Danube supermarkets provide their customers with online shopping, promotions activities, high variety, availability and high quality of goods. Nevertheless, they enhance the customer communication through their website, YouTube channels and other social media communication, all of which provide the customer with important 
Table 2. Suggestions to increase customer knowledge about loyalty programs.

\begin{tabular}{cccc}
\hline $\begin{array}{c}\text { Suggestions to increase customer knowledge } \\
\text { about loyalty programs }\end{array}$ & Response (\%) & Mean & Ranking \\
\hline Brochures & 20.1 & 20.1 & $\mathbf{2}$ \\
Poster & 11.3 & 11.3 & $\mathbf{4}$ \\
SMS messages & 49.5 & 49.5 & $\mathbf{1}$ \\
Internet advertising & 19.1 & 19.1 & $\mathbf{3}$ \\
$\mathbf{N}=\mathbf{2 0 0}$ & $\mathbf{1 0 0}$ & & \\
\hline
\end{tabular}

Table 3. The favorite loyalty programs for customers.

\begin{tabular}{cccc}
\hline The favorite rewards system for customers & Response (\%) & Mean & Ranking \\
\hline Loyalty card & 20.6 & 20.6 & $\mathbf{2}$ \\
Voucher & 9.8 & 9.8 & $\mathbf{4}$ \\
Discounts & 49.5 & 49.5 & $\mathbf{1}$ \\
Free goods & 20.1 & 20.1 & $\mathbf{3}$ \\
$\mathbf{N}=\mathbf{2 0 0 0}$ & $\mathbf{1 0 0}$ & & \\
\hline
\end{tabular}

information such as the latest promotions, goods availability, new goods, etc (Danube Co.). Panda supermarkets enhance their customer satisfaction through weekly promotions, high variety of goods, availability and quality. They have also developed a Panda connect program in addition to their website (Panda). This program concentrates on enhancing customer communication through the Panda application, which is available in APP and Android stores. Furthermore, they provide the customer with communication channels on all social media such as Facebook, Twitter, Instagram and YouTube (Panda). The loyalty programs that are applied by Danube and Panda supermarkets have a strong impact on customer loyalty and the survey results supported this. However, the study found that most of the consumers were interested in loyalty programs, as shown in Table 3, but do not have complete awareness about them. Customers need to enhance their knowledge through SMS massages brochures, and internet advertisements. Participants suggested that supermarkets offering them loyalty cards in order to help them increase their loyalty and purchasing activities. However, they prefer discount promotions more than loyalty cards, as shown in Table 3. The majority believe that it would increase their purchasing activities. Therefore, the supermarkets' management has to make an effort to improve CRM in order to enhance customer loyalty and support word-of-mouth communication, which is a powerful promotional and advertising tool. Word of mouth communication should be considered as part of the business marketing strategy since the study found that when customers tell their friends and family about their experience with the supermarket. Therefore, the positive word-of-mouth communication will be reached if customers had a good experience while visiting the supermar- 
ket and if all their needs were satisfied. This means that customer satisfaction and loyalty are the major factors affecting word-of-mouth communication. Nikhashemia, Paimb, Osmanc, and Sidind (2015) and Terblanche (2011) found the same result about this kind of marketing strategy. However, the study illustrates that the family size and income impact loyalty indirectly. Nevertheless, most of the targeted populations were loyal to the supermarkets if it is satisfied their expectations and needs.

Table 4 shows that the study classified customer loyalty into five groups, according to customer's satisfaction category.

\subsection{Customer Loyalty Group I: Price}

Group I loyalty depends on the provided price. Therefore, they are loyal to the supermarkets that provide them with the lowest price. They do not care about the variety, availability of the products or the location. To satisfy this category, the supermarkets have to decline the unit costs and be more efficient. Unit costs decline by increasing economic scale and product aggregation, which is produced by utilizing the capacity of storage and transportation. This utilization will decrease the number of supermarket facilities, which will lead to reduce inventory and transportation costs.

\subsection{Customer Loyalty Group II: Variety of Products}

This group is satisfied if the supermarket provides high variety of products. Therefore, to satisfy them the supermarkets have to be more responsible than being efficient. The responsible supermarket tends to respond to a higher range of demand which increase costs.

\subsection{Customer Loyalty Group III: Promotion Activities}

To satisfy this group, supermarkets have to provide continuous promotion activities. They might provide discount, Buy 1 Get 1 free, weekly, and monthly or holiday promotions.

\subsection{Customer Loyalty Group IV: Membership}

Some customers are more loyal to the supermarkets that provide their customer with membership cards (also called loyalty cards). These cards help customers

Table 4. Customer loyalty groups.

\begin{tabular}{ccc}
\hline Customer Loyalty Groups & Response (\%) & Ranking \\
\hline Customer Loyalty Group I: Price & 40.8 & $\mathbf{2}$ \\
Customer Loyalty Group II: Variety of products & 40.8 & $\mathbf{2}$ \\
Customer Loyalty Group III: Promotion activities & 40.6 & $\mathbf{3}$ \\
Customer Loyalty Group IV: Membership & 40.4 & $\mathbf{4}$ \\
Customer Loyalty Group V: Supermarket location & 41.8 & $\mathbf{1}$ \\
\hline
\end{tabular}


get a discount on a current purchase or to collect points that they can use for future purchases. Furthermore, this is a benefit to supermarkets as can they use these cards to analyze individual customer information. It helps supermarkets to find the shopping patterns, variation and frequency of purchases, and also to find out favorite brands. Therefore, they can email discount coupons or offers for each customer based on their previous purchases. However, this strategy is not effective for customers who want instant impacts such as groups I and III.

\subsection{Customer Loyalty Group Vs Supermarket Location}

For some customers, supermarket location is important. To satisfy this group, supermarkets need to be more responsible by increasing the number of its facilities. This will decrease the response time for the customer to get his order.

A conceptual framework is provided in Figure 1. The conceptual framework conducts the main results that were retrieved through the field survey. It presents the independents' variables that affect customer satisfaction and loyalty. The independent variables are customer services quality and customer relationship improvement, which have a direct impact on improving CRM of the supermarket. In addition, Long and Khalafinezhad (2012) found the same results but they consider the behavior of the employee with the customer and relationship management as independent variables beside services quality and customer relationship improvement. Customer services quality is concentrated on providing the customers with all their needs such as product availability, variety, order visibility, return ability, response time and time to market. Product variety is obtained by increasing the number of products offered by the supermarkets while the availability is acquired by increasing the probability of having a product in stock. Order visibility is the ability of customers to track their products. To improve order visibility, supermarkets need to classify their products into separate sections such as food, cleaning suppliers, electronics, health and beauty, etc. Return ability refers to the ease with which a customer can return unsatisfactory goods. Response time is the time it takes the customer to receive an order. Time to market refers to the amount of time required to bring new products to the supermarket. Furthermore, the second independent variable which is customer relationship improvement, concentrates on enhancing and utilizing the relationship between the supermarket and the customer. Supermarkets can improve their relationship with the customer by providing new communication methods such as providing official accounts in all social media. In addition, they can provide mobile applications to inform customers of new offers or products and promotions. Table 2 shows that they also can use SMS messages, a website or Internet advertisements. These two independent variables have a direct impact on CRM since it refers to the management of all the processes that focus on the interface between the supermarket and its customer. The improvement in CRM will enhance customer satisfaction, which in turn will enhance customer loyalty. 


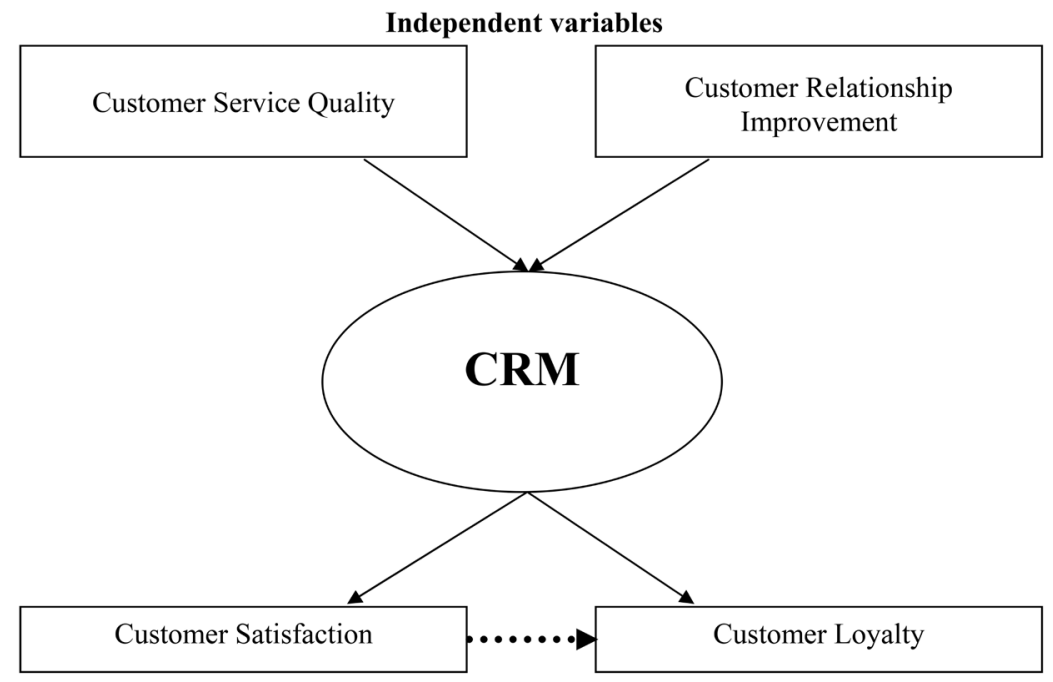

Dependent variables

Figure 1. Conceptual framework.

\section{Conclusion}

This study includes a literature review and field survey of customer loyalty to find the main factors that affect customer satisfaction using customer relationship management (CRM) to analyze and find out the potential factors that could improve satisfaction. Customer loyalty is achieved through how much the supermarkets are willing to provide the best services that they could have. Customer loyalty can be enhanced through several factors such as discounts, membership and availability of products. The primary importance in respect of customer loyalty and supermarket owners is service quality, offering more products with more flexibility and reasonable prices. Future studies might study the successful retailers worldwide to come up with new innovative techniques to increase customer loyalty.

\section{Conflicts of Interest}

The author declares no conflicts of interest regarding the publication of this paper.

\section{References}

Danube Co. (n.d.). http://www.danubeco.com/app

Gandhi, R. K., Gobiraj, V., \& Nimalathasan, B. (2010). Determinants of Customer Loyalty in Leading Retail Supermarkets in United Kingdom: An Exploratory Study. SRM Management Digest, 8, 95-106.

Gobiraj, V., \& Nimalathasan, B. (2011). Customer Satisfaction and Customer Loyalty: A Case Study of Retail Super Markets in United Kingdom (UK). In The International Conference on Leading beyond the Horizon: Engaging Future. Sri Sai Ram Institute of Management Studies.

Ho, R. (2009). An Approach to Develop Effective Customer Loyalty Programs the VIP Program at T\&T Supermarkets Inc. Managing Service Quality: An International Jour- 
nal, 19, 702-720. https://doi.org/10.1108/09604520911005080

Khan, M. T. (2013). Customers Loyalty: Concept \& Definition (A Review). International Journal of Information, Business and Management, 5, 168-191.

Kotler, P. (2003). Marketing Insights from A to Z: 80 Concepts Every Manager Needs to Know. John Wiley \& Sons.

Long, C. S., \& Khalafinezhad, R. (2012). Customer Satisfaction and Loyalty: A Literature Review in the Perspective of Customer Relationship Management. Journal of Applied Business and Finance Researches, 1, 6-13. https://doi.org/10.11113/jt.v64.2237

Moisescu, O. (2014). Assessing Customer Loyalty.

Nikhashemia, S., Paimb, L., Osmanc, S., \& Sidind, S. (2015). The Significant Role of Customer Brand Identification towards Brand Loyalty Development. An Empirical Study among Malaysian Hypermarkets Customer. Procedia-Social and Behavioral Sciences, 207, 182-188. https://doi.org/10.1016/j.sbspro.2015.10.086

Panda. (n.d.). http://beta.panda.com.sa/stores/jeddah

Ranade, K. (2012). Loyalty Research Centre. Retrieved from Insight/Customer Loyalty-What Is It? And How Can You Measure It?

Reichheld, F. F. (2003). The One Number You Need to Grow. Harvard Business Review, 81, 46-55.

Salegna, G. J., \& Goodwin, S. A. (2005). Consumer Loyalty to Service Providers: An Integrated Conceptual Model. Journal of Consumer Satisfaction, Dissatisfaction and Complaining Behavior, 18, 51.

Terblanche, N. (2011). The Mediating Role of Customer Satisfaction and Loyalty in Predicting the Word-of-Mouth of Supermarket Customers. Management Dynamics, 20, 23-37. 